\title{
Impact of atmospheric deposition on the contrasting iron biogeochemistry of the North and South Atlantic Ocean
}

\author{
Simon J. Ussher, ${ }^{1,2}$ Eric P. Achterberg, ${ }^{3}$ Claire Powell, ${ }^{4}$ Alex R. Baker, ${ }^{4}$ Tim D. Jickells, ${ }^{4}$ \\ Ricardo Torres, ${ }^{5}$ and Paul J. Worsfold ${ }^{1}$ \\ Received 25 July 2012; revised 25 March 2013; accepted 12 June 2013; published 13 November 2013.
}

[1] Dissolved iron (dFe) distributions and atmospheric and vertical subduction fluxes of $\mathrm{dFe}$ were determined in the upper water column for two meridional transects of the Atlantic Ocean. The data demonstrate the disparity between the iron biogeochemistry of the North and South Atlantic Ocean and show well-defined gradients of size fractionated iron species in surface waters between geographic provinces. The highest $\mathrm{dFe}$ and lowest mixed layer residence times (0.4-2.5 years) were found in the northern tropical and subtropical regions. In contrast, the South Atlantic Gyre had lower dFe concentrations $(<0.4 \mathrm{nM})$ and much longer residence times ( $>5$ years), presumably due to lower atmospheric inputs and more efficient biological recycling of iron in this region. Vertical input fluxes of dFe to surface waters ranged from 20 to $170 \mathrm{nmol} \mathrm{m}^{-2} \mathrm{~d}^{-1}$ in the North Atlantic and tropical provinces, whereas average fluxes of $6-13 \mathrm{nmol} \mathrm{m}^{-2} \mathrm{~d}^{-1}$ were estimated for the South Atlantic. Our estimates showed that the variable $\mathrm{dFe}$ distribution over the surface Atlantic $(<0.1-2.0 \mathrm{n} M)$ predominantly reflected atmospheric Fe deposition fluxes $(>50 \%$ of total vertical Fe flux to surface waters) rather than upwelling or vertical mixing. This demonstrates the strength of the connection between land-derived atmospheric Fe fluxes and the biological cycling of carbon and nitrogen in the Atlantic Ocean.

Citation: Ussher, S. J., E. P. Achterberg, C. Powell, A. R. Baker, T. D. Jickells, R. Torres, and P. J. Worsfold (2013), Impact of atmospheric deposition on the contrasting iron biogeochemistry of the North and South Atlantic Ocean, Global Biogeochem. Cycles, 27, 1096-1107, doi:10.1002/gbc.20056.

\section{Introduction}

[2] Phytoplankton growth is limited by iron availability in approximately one third of the world's oceans, and global export production is highly sensitive to iron fluxes from atmospheric deposition [Moore et al., 2002; Parekh et al., 2004]. Hence, knowledge of the spatial distribution and atmospheric fluxes of iron in the ocean is required to improve our understanding of its role in regulating primary production. The rate of primary production in the Atlantic is largely controlled by the availability of inorganic and organic macronutrients ( $\mathrm{N}$ and $\mathrm{P}$ ) delivered predominantly by in situ processes (e.g., nitrogen fixation) or by physical transport (e.g., diapycnic transfer) [Mahaffey et al., 2004]. However,

\footnotetext{
Additional supporting information may be found in the online version of this article.

${ }^{1}$ School of Geography, Earth and Environmental Sciences, University of Plymouth, Plymouth, UK.

${ }^{2}$ Bermuda Institute of Ocean Sciences, Ferry Reach, St. George's, Bermuda.

${ }^{3}$ National Oceanography Centre, Southampton, University of Southampton, Southampton, UK.

${ }^{4}$ Laboratory for Global Marine and Atmospheric Chemistry, School of Environmental Sciences, University of East Anglia, Norwich, UK.

${ }^{5}$ Plymouth Marine Laboratory, Plymouth, UK.

Corresponding author: S. J. Ussher, School of Geography, Earth and Environmental Science, University of Plymouth, Plymouth PL4 8AA, UK. (sussher@plymouth.ac.uk)

C2013. American Geophysical Union. All Rights Reserved. 0886-6236/13/10.1002/gbc.20056
}

the dynamic nature of $\mathrm{dFe}$ supply and short residence times in the surface mixed layer ( $<2$ years) [Bergquist et al., 2007; Jickells, 1999; Sarthou et al., 2003] means that the spatial and temporal variation in the distribution of Fe in Atlantic surface waters can affect important processes, such as rates of primary production and bloom formation [Blain et al., 2004; Martin et al., 1993; Moore et al., 2006] as well as rates of nitrogen fixation in tropical and subtropical regions [Mills et al., 2004; Moore et al., 2009].

[3] Recent studies indicated that hydrothermal contributions of $\mathrm{dFe}$ to the upper water column $(0-300 \mathrm{~m})$ in the Atlantic are negligible [Tagliabue et al., 2010] and that surface $\mathrm{dFe}$ gradients from shelf regions generally do not extend beyond approximately $1000 \mathrm{~km}$ from continental shelves [Elrod et al., 2004; Ussher et al., 2007]. However, a major source of Fe to the remote North Atlantic is the transport and deposition of atmospherically processed aerosols and precipitation [Baker et al., 2006a; Buck et al., 2010a, 2010b; Duce and Tindale, 1991; Helmers and Schrems, 1995]. The main vectors for this process are the seasonally oscillating Saharan dust plume (approximately $0^{\circ}-30^{\circ} \mathrm{N}$ ) [Kaufman et al., 2005] and the Inter Tropical Convergence Zone (ITCZ) at its southern extent $\left(5^{\circ} \mathrm{S}-15^{\circ} \mathrm{N}\right)$. Dust inputs to the South Atlantic are weaker, with important consequences for biogeochemical cycles [Moore et al., 2009].

[4] To assess the importance of regional atmospheric deposition on Fe distributions in the upper water column of the Atlantic Ocean, we present $\mathrm{dFe}$ data from two Atlantic 


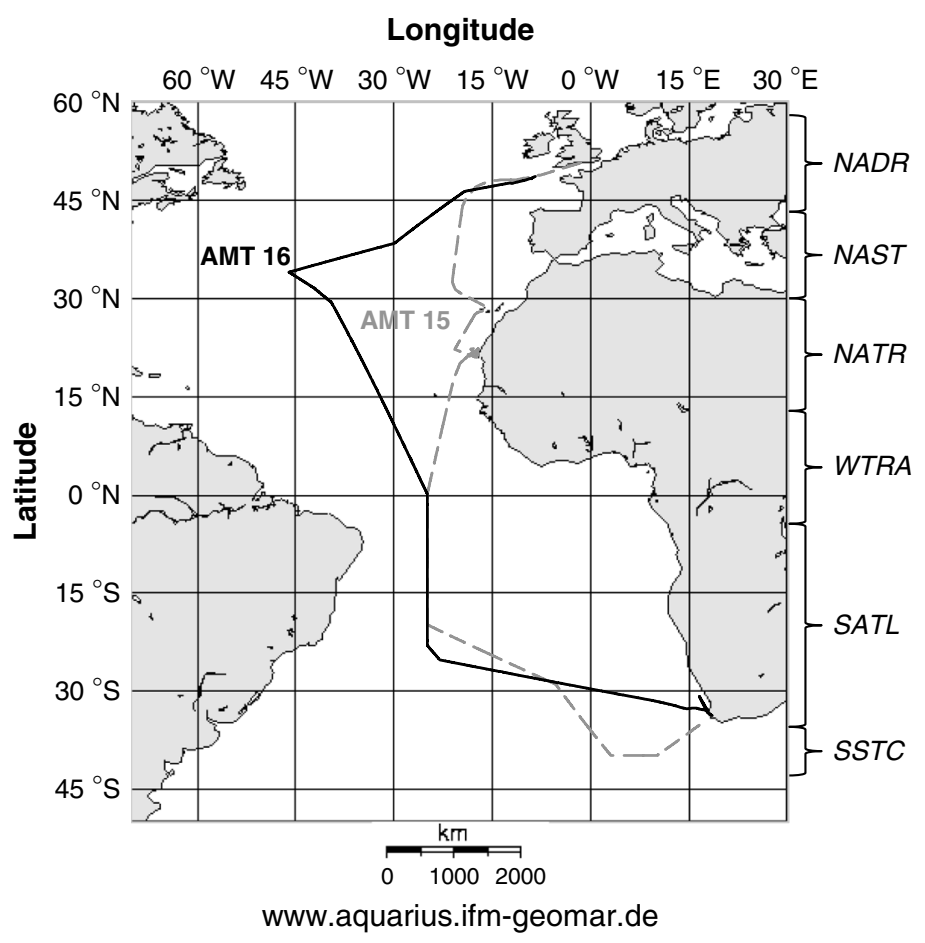

Figure 1. The Atlantic Meridional Transects (AMT) 15 and 16 cruise tracks in the Atlantic Ocean (2004-2005). Geographic provinces are indicated as North Atlantic Drift (NADR), North Atlantic Subtropical Gyre (NAST), North Atlantic Tropical Gyre (NATR), Western Tropical Atlantic (WTRA), South Atlantic Gyre (SATL), and South Subtropical Convergence (SSTC).

Meridional Transects (AMT15 and AMT16). Atmospheric deposition is highly variable within time scales shorter than surface water dFe residence times [Duce and Tindale, 1991; Sarthou et al., 2003]. Therefore, to estimate vertical fluxes and residence times, we provide both in situ (instantaneous) and seasonal (interannual 3 month average) atmospheric $\mathrm{Fe}$ fluxes for Atlantic regions and calculate the vertical transport of $\mathrm{dFe}$ across the thermocline into the surface mixed layer from physical oceanographic data.

\section{Materials and Methods}

\subsection{Seawater Sampling and Processing}

[5] Trace metal sampling was conducted between the surface and upper water column $(0-300 \mathrm{~m})$ in the temperate, subtropical, and tropical regions of the Atlantic Ocean (Figure 1) on board the RRS Discovery (UK). "AMT15" was a transect from Southampton, UK, to Cape Town, South Africa (17 September to 29 October 2004), and "AMT16" took place the following year between Cape Town, South Africa, and Falmouth, UK (20 May to 28 June 2005). The cruise track for AMT15 deviated from open ocean North Atlantic waters into the shelf waters of the Mauritania upwelling region (approximately $20^{\circ} \mathrm{N}, 18^{\circ} \mathrm{W}$ ) whereas the AMT16 track headed to a waypoint at the center of the North Atlantic subtropical gyre (approximately $34^{\circ} \mathrm{N}$, $46^{\circ} \mathrm{W}$ ). Cruise tracks were identical between the equator and $20^{\circ} \mathrm{S}$, but during AMT15, the ship headed farther south to sample the productive waters of the southern subtropical convergence zone (approximately $40^{\circ} \mathrm{S}$ ). The provinces indicated were defined according to Longhurst [1998] and are listed in Table A1 in the supporting information.
[6] High-purity water (deionized (DI) water, $18.2 \mathrm{M} \Omega \mathrm{cm}$ ) was used for all rinses, reagents, and standards, and all sample storage bottles were low-density polyethylene (LDPE) bottles (Nalgene, UK). Sample bottles and other plastic labware were cleaned by sequential 10 day soaks in $1 \%$ Decon $^{\mathrm{TM}}, 50 \% \mathrm{HCl}$ (Aristar ${ }^{\mathrm{M}}$ Grade, VWR), and 20\% $\mathrm{HNO}_{3}$ (Aristar ${ }^{\mathrm{TM}}$ Grade, VWR). Following this, they were rinsed three times with DI water and filled with ultrapure $0.01 \mathrm{M} \mathrm{HCl}$ (Romil-UpA ${ }^{\mathrm{TM}}$, Romil, UK) until used. All sample handling and processing was conducted in a laminar flow hood in a trace metal clean container.

[7] Filtered and unfiltered underway surface samples were pumped through acid-washed LDPE tubing from a trace metal towed fish which was deployed on the port side of the ship to a depth of $\sim 5 \mathrm{~m}$. Subsurface samples were collected using a titanium alloy conductivity-temperature-depth (CTD) frame deployed on a new stainless steel wire, using modified 10 L Ocean Test Equipment ${ }^{\mathrm{TM}}$ sample bottles (Model 110). Seawater samples were processed for different size fractions of $\mathrm{Fe}$, defined as follows: soluble iron $(\mathrm{sFe}<0.02 \mu \mathrm{m})$, dissolved iron $(\mathrm{dFe},<0.2 \mu \mathrm{m})$, and total dissolvable iron (TDFe, unfiltered seawater). Sartobran ${ }^{\mathrm{TM}}$ cartridges $(0.2 \mu \mathrm{m}$ cutoff, Sartorius) and PTFE membrane syringe filters $(0.2 \mu \mathrm{m}$ cutoff, GD/X ${ }^{\mathrm{TM}}$, Whatman) were used for underway and discrete hydrocast samples, respectively. For the soluble size fraction, precleaned Anotop ${ }^{\mathrm{TM}}$ syringe filters $(25 \mathrm{~mm}, 0.02 \mu \mathrm{m}$ pore size, Whatman) were connected in-line to a six-channel peristaltic pump (Gilson Minipuls $3^{\mathrm{TM}}$ ). All filtered and unfiltered samples were acidified with $\mathrm{HCl}$ (UltraPure, Romil, UK) at a ratio of $1 \mathrm{~mL} \mathrm{~L}^{-1}$. The sample bottles were then sealed tightly, triple bagged, and stored in a cool room for $>6$ months before analysis on land. To check for 

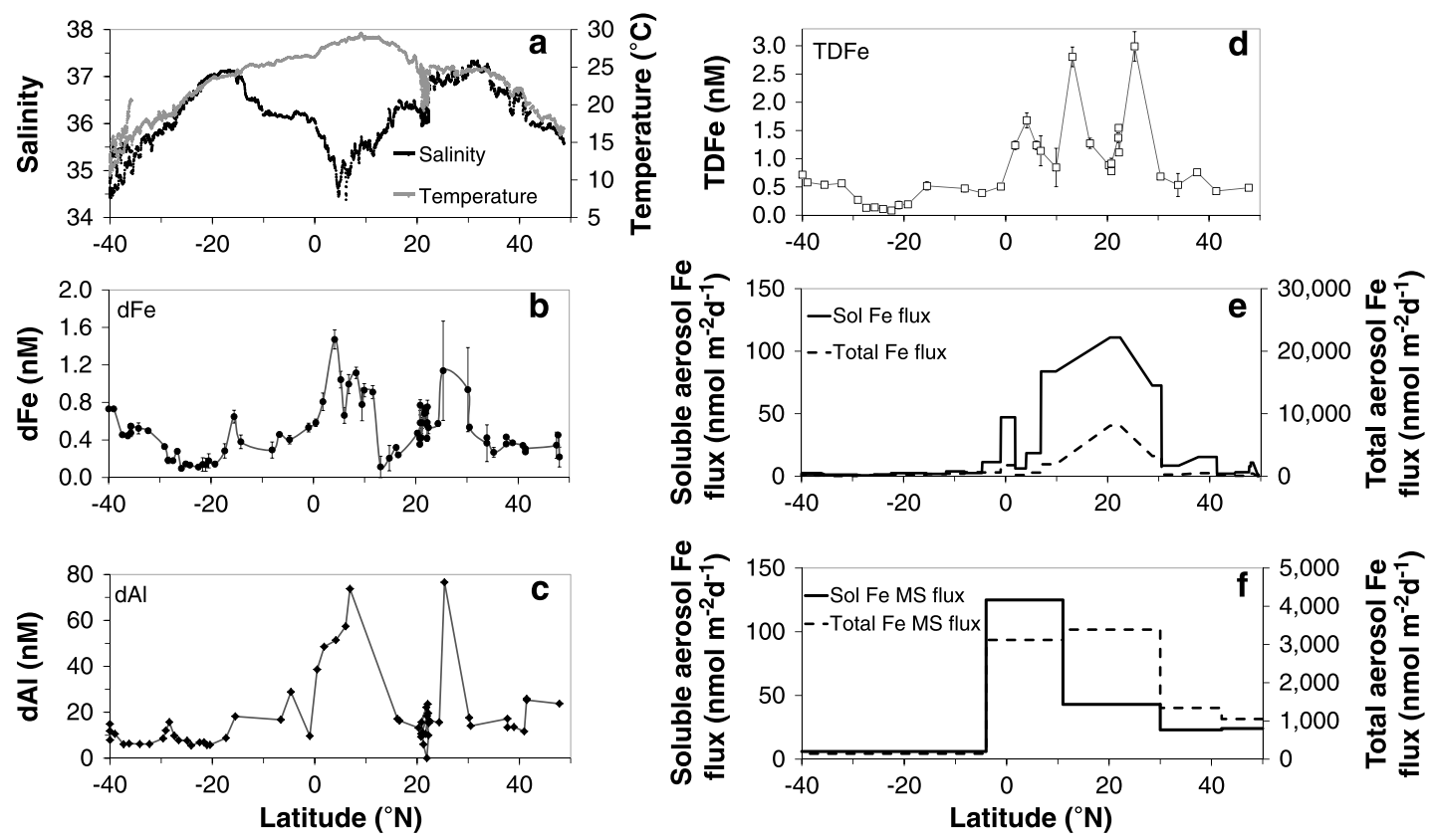

Figure 2. Surface meridional transect data from the AMT15 cruise. (a) Underway salinity and temperature. (b) Dissolved iron (dFe). (c) Dissolved aluminum (dAl). (d) Total dissolvable iron (TDFe). (e) In situ aerosol soluble and total iron fluxes (solid and dashed lines, respectively). (f) Mean seasonal (MS) (September-November) soluble and total iron fluxes (solid and dashed lines, respectively). Error bars show the standard deviation of four analytical replicates. Horizontal lines in Figures $2 \mathrm{e}$ and $2 \mathrm{f}$ are mean atmospheric fluxes over the distance indicated and any slopes between these are interpolated.

contamination, $\mathrm{dFe}$ was determined on board in selected samples and blanks on a weekly basis. Further details of the sampling and processing can be found in the supporting information.

\subsection{Determination of Iron and Aluminum in Seawater}

[8] Iron in size fractionated seawater samples $(\mathrm{sFe}, \mathrm{dFe}$, and TDFe) was determined using flow injection with chemiluminescence detection (FI-CL). This used luminol as the chemiluminescence reagent and employed a sulfite reduction step (spiked addition of sodium sulfite to make a final concentration of $0.1 \mathrm{~m} M, 12 \mathrm{~h}$ reaction time) prior to determination of $\mathrm{Fe}$ (II) [Bowie et al., 1998]. Further details of the method can be found in the supporting information. The between-batch consistency of $\mathrm{dFe}$ analysis and the within-batch drift were checked by analyzing the IRONAGES reference seawater [Bowie et al., 2006] and an in-house reference seawater with each batch of samples. Analysis of SAFe S1 and D2 seawater reference materials gave $0.18 \pm 0.02 \mathrm{n} M$ and $0.93 \pm 0.04 \mathrm{n} M$, respectively (consensus values were 0.097 $\pm 0.043 \mathrm{n} M$ and $0.91 \pm 0.17 \mathrm{n} M$, respectively [Johnson et al., 2007]). Two blind intercomparisons with an inductively coupled plasma-mass spectrometry method were also performed using Atlantic open ocean and shelf samples and gave good agreement within the range 0.2-2.0 $\mathrm{n} M$ [Bowie et al., 2007; Ussher et al., 2010].

[9] Surface dAl was determined by reaction with lumogallion (2,2',4'-trihydroxy-5-chloroazobenzene-3-sulfonic acid) followed by fluorescence detection $\left(\lambda_{\text {ex }} 465 \mathrm{~nm}, \lambda_{\text {em }} 555\right.$ nm) using a batch method [Hydes and Liss, 1976]. No open ocean reference materials were available for $\mathrm{dAl}$ at the time of analysis, and hence, oceanographic consistency was checked by comparison with Atlantic data from other workers [Measures et al., 2008].

\subsection{Atmospheric Sampling and Analysis}

[10] Samples for aerosol trace metal analysis were collected using high-volume $\left(1 \mathrm{~m}^{3} \mathrm{~min}^{-1}\right)$ collectors mounted on the wheelhouse roof of the vessel. During AMT15, the collector was equipped with a three-stage Sierra-type cascade impactor head, while bulk $(20 \times 25 \mathrm{~cm})$ samples were collected during AMT16. For both cruises, aerosol collection substrates (Whatman 41 cellulose) were acid washed before use to reduce trace metal blanks, first in $0.5 \mathrm{M} \mathrm{HCl}$ and then in $0.1 \mathrm{M} \mathrm{HNO}_{3}(\mathrm{AMT} 15)$ or $0.1 \mathrm{M} \mathrm{HCl}$ (AMT16). Sample filters were generally changed every 1-2 days (average air volume sampled $\left.\sim 1400-2800 \mathrm{~m}^{3}\right)$ during AMT15, or every 2-3 days during AMT16 $\left(\sim 2800-4200 \mathrm{~m}^{3}\right)$. Wind direction was continuously monitored and the sampler was switched off if there was a risk of contamination from the ship's exhaust. After sampling, the filters were stored in separate sealed plastic bags, frozen immediately, and returned to the laboratory for later analysis. Detailed methods can be found elsewhere [Baker et al., 2006b; Rijkenberg et al., 2012] and procedural blank data can be found in Table S2 in the supporting information.

[11] Rain samples were collected by manually opening rain collectors (LDPE bottles attached to $40 \mathrm{~cm}$ diameter polypropylene funnels) immediately prior to, or at the onset of, rain and closing them upon the cessation of rain. Rain sampling equipment was cleaned by soaking in $10 \% \mathrm{vol} / \mathrm{vol} \mathrm{HNO}_{3}$ for at least $48 \mathrm{~h}$ before use, and bottles were stored filled with DI water acidified with $1 \mathrm{~mL} \mathrm{~L}^{-1}$ concentrated Aristar $\mathrm{HNO}_{3}$ [Baker et al., 2007]. Blanks for rain sampling were 

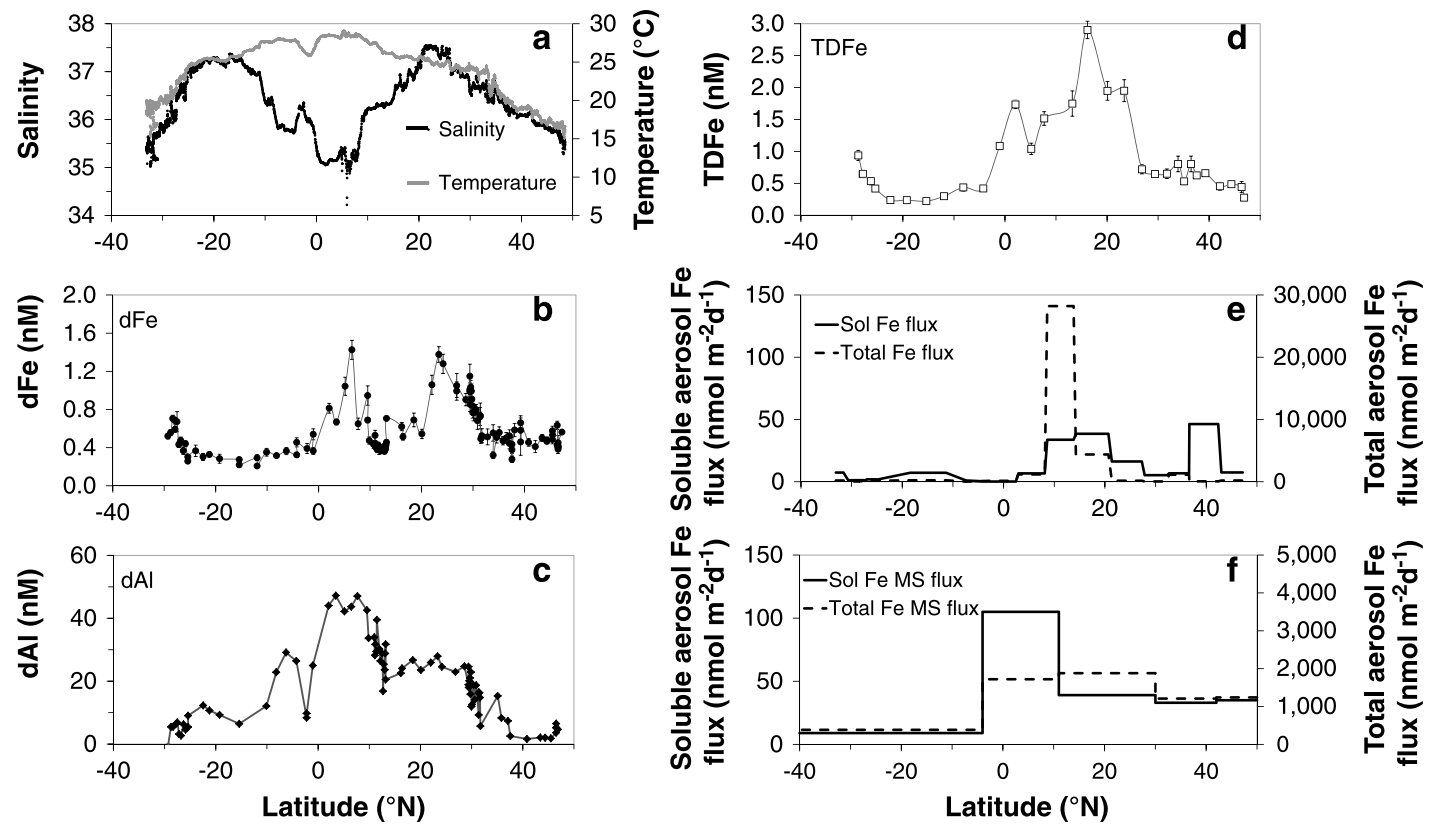

Figure 3. Surface meridional transect data from the AMT16 cruise. (a) Underway salinity and temperature. (b) Dissolved iron (dFe). (c) Dissolved aluminum (dAl). (d) Total dissolvable iron (TDFe). (e) In situ aerosol soluble and total iron fluxes (solid and dashed lines, respectively). (f) Mean seasonal (MS) (April-June) soluble and total iron fluxes (solid and dashed lines, respectively). Error bars show the standard deviation of four analytical replicates. Horizontal lines in Figures $3 \mathrm{e}$ and $3 \mathrm{f}$ are mean fluxes over the distance indicated and any slopes between these are interpolated.

determined during each cruise by collecting acidified $(1 \mathrm{~mL}$ $\mathrm{L}^{-1}$ concentrated $\mathrm{HNO}_{3}$ ) DI water that had been used to rinse the collection surfaces of the rain funnels and determining the trace metal content of this rinse water. Samples were frozen immediately, without filtration, and were subsequently acidified as above and left to stand for at least 2 weeks before analysis.

[12] Soluble aerosol Fe and Al concentrations were determined by inductively coupled plasma-optical emission spectrometry (ICP-OES, Varian) after extraction of a portion of each filter in ammonium acetate solution ( $\mathrm{pH} 4.7)$ and subsequent filtration of the extract through $0.2 \mu \mathrm{m}$ filters [Baker et al., 2007]. Unfiltered, acidified rain samples were analyzed for $\mathrm{Fe}$ and $\mathrm{Al}$ concentrations using the same ICP-OES instrument. Total Fe and $\mathrm{Al}$ concentrations were determined by instrumental neutron activation analysis (INAA) of separate portions of the filters. For AMT15, soluble Fe and Al determination was carried out separately for the submicron and supermicron aerosol size fractions, but INAA was done using all size fractions combined, so that only bulk total $\mathrm{Fe}$ and $\mathrm{Al}$ concentrations are available for this cruise.

\subsection{Supporting Oceanographic Data}

[13] Underway and CTD physical data were obtained from FSI OCM (ocean conductivity module, Falmouth Scientific Inc.) conductivity and temperature sensors operated by the National Marine Facilities (Southampton, UK). The CTD temperature and conductivity sensors were calibrated against discrete samples measured on a salinometer (Autosal, Guideline). Dissolved oxygen was determined using a SBE 43 Oxygen sensor and calibrated with dissolved oxygen data determined by Winkler titration. Ocean Data View software was used to plot the vertical AMT sections (http:// odv.awi.de, 2008).

\section{Results and Discussion}

\subsection{Surface Water dFe and dAl Distributions}

[14] Surface water $\mathrm{dFe}$ and TDFe were compared with atmospheric fluxes and physical variables (temperature and salinity) for both AMT cruises (Figures 2 and 3). This included $\mathrm{dAl}$, as a proxy for atmospheric deposition (Figures 2c and 3c). Data from rain and aerosol samples were used to calculate total instantaneous atmospheric $\mathrm{Fe}$ deposition (Figures 2e and 3e), and mean seasonal $\mathrm{Fe}$ deposition was calculated from (i) three cruises, including AMT16, for the period of April-June, and (ii) nine cruises, including AMT15, for the period of September-November (Figures $2 \mathrm{f}$ and $3 \mathrm{f}$ ). Dry deposition fluxes in these calculations were estimated using particle size- and wind speeddependent deposition velocities, as described in Baker et al. [2010, 2013]. A consistent contrast in the iron distributions between the North and South Atlantic was observed for both AMT15 and AMT16 transects. Minimum surface dFe concentrations $(<0.1-0.4 \mathrm{n} M)$ were found in the center of the South Atlantic Gyral Province (SATL) between $15^{\circ} \mathrm{S}$ and $30^{\circ} \mathrm{S}$ and increased moving north over the equator in concert with $\mathrm{dAl}$ and in situ atmospheric $\mathrm{Fe}$ and $\mathrm{Al}$ fluxes. In accordance with the known extent of the Saharan dust plume, the maximum $\mathrm{dFe}$ and TDFe concentrations were found between $0^{\circ}$ and $30^{\circ} \mathrm{N}$ in the Western Tropical Atlantic Province (WTRA) and the North Atlantic Tropical Gyre Province (NATR). The $\mathrm{dFe}$ concentrations decreased northward into the North Atlantic Subtropical Gyre (NAST) at approximately $30^{\circ} \mathrm{N}$ 


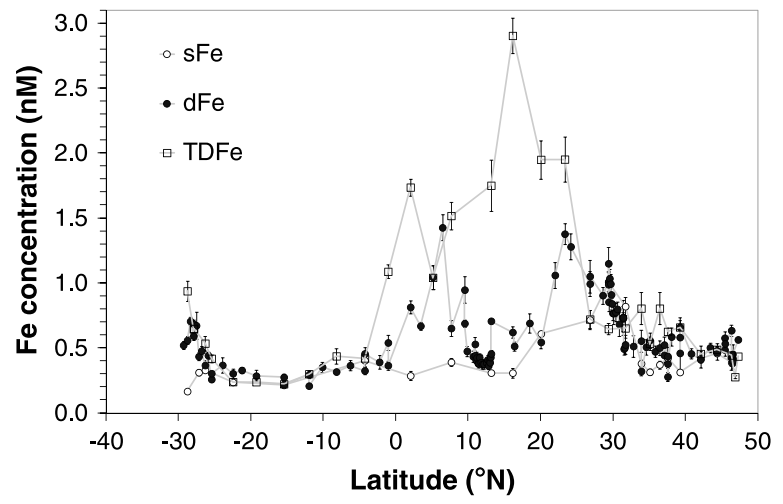

Figure 4. Surface water Fe size speciation for AMT16, showing soluble iron $(\mathrm{sFe},<0.02 \mu \mathrm{m})$, dissolved iron $(\mathrm{dFe},<0.2$ $\mu \mathrm{m}$ ), and total dissolvable iron (TDFe, unfiltered seawater).

and the North Atlantic Drift (NADR), where they remained lower and less variable $(0.2-0.6 \mathrm{n} M)$ until the approach to the European shelf break.

[15] The well-defined decrease in $\mathrm{dFe}, \mathrm{TDFe}, \mathrm{dAl}$, and in situ atmospheric concentrations of $\mathrm{Fe}$ and $\mathrm{Al}$, north of $30^{\circ} \mathrm{N}$ for AMT16 (Figure 3), demonstrated the latitudinal limit of the main Saharan dust plume. This gradient in both $\mathrm{dFe}$ and dAl agreed with observations from other studies [Bergquist et al., 2007; Bowie et al., 2002; Buck et al., 2010a; Measures et al., 2008; Shelley et al., 2012] and was consistent with model studies [Mahowald et al., 2009], confirming this to be a permanent interannual feature, likely strengthened by medium-strong winter mixing (downward subduction) in the NAST $\left(>30^{\circ} \mathrm{N}\right)$ compared with weak seasonal mixing in the NATR $\left(12^{\circ} \mathrm{N}-30^{\circ} \mathrm{N}\right)$ [Longhurst, 1998].

[16] Toward the southern extent of the Saharan dust plume, a second maximum in surface $\mathrm{dFe}(0.8-1.6 \mathrm{n} M)$ was observed for both cruises between $5^{\circ} \mathrm{N}$ and $13^{\circ} \mathrm{N}$, where intense rain showers were recorded during both cruises. These features occurred in concert with a surface salinity minimum $(<35)$ (Figures 2a and 3a) and a maximum dAl concentration $(>40 \mathrm{nM})$. Both $\mathrm{dFe}$ and dAl showed a significant correlation with salinity in this region for AMT15 $\left(\mathrm{r}^{2}=0.67\right.$ and $0.51, \mathrm{n}=16$ and 9, respectively) and AMT16 $\left(\mathrm{r}^{2}=0.57\right.$ and $0.52, \mathrm{n}=31$ and 23). This suggests that high atmospheric particle concentrations combined with scavenging by rainfall in the ITCZ were a major source of $\mathrm{dFe}$ to the surface waters of the WTRA, consistent with the complex meteorological interactions in this area, resulting in high rainfall on the northern edge of the ITCZ intensified by dust outbreaks, as described by Wilcox et al. [2010]. This feature was observed during boreal spring/summer and autumn; hence, it is likely to continue through the winter, although the salinity minimum will move south as the ITCZ oscillates. Indeed, similar $\mathrm{dFe}$ maxima have been observed in other Atlantic transects across the ITCZ in October 2000 (0.74 $\mathrm{n} M$ [Sarthou et al., 2003]), March $2002(\sim 0.7 \mathrm{n} M$ [Bergquist et al., 2007]), and June-August 2003 ( 1.2 nM [Measures et al., 2008]).

[17] Evidence indicated that the seasonal retroflection of the Amazon plume was not the main cause of the high-dFe, lowsalinity feature in both AMT15 and AMT16. The plume can feed into the rapid northern equatorial counter current (NECC, $3^{\circ} \mathrm{N}-10^{\circ} \mathrm{N}$ ); however, no elevation in surface silicate concentration (i.e., $>1.5 \mu M$ ), which would be indicative of Amazon inputs, was observed in either AMT15 or AMT16 surface samples. Second, the NECC flows at full strength $\left(\sim 40 \mathrm{~cm} \mathrm{~s}^{-1}\right)$ during boreal summer [Fratantoni, 2001]; therefore, this situation would have been unlikely during AMT16 (May-June 2005) as efficient advection of the Amazon plume by the Brazil Current retroflection occurs between July and October [Lentz, 1995]. Measures et al. [2008] suggested that high productivity and utilization of nutrients advected within the plume cause the removal of $\mathrm{dFe}$. Furthermore, clear maxima in $\mathrm{dFe}$ and total dissolvable $\mathrm{Fe}$ and $\mathrm{Al}$ (unfiltered acidified samples) that coincide with a surface salinity minimum have been observed even farther east $\left(\sim 15^{\circ} \mathrm{W}\right)$ than this study [Bowie et al., 2002; Sarthou et al., 2003].

[18] The surface salinity minima on the AMT transects were lower than the salinity of upwelled water $(\sim 35-36)$ below the mixed layer in this region, suggesting that upwelling and/or spatial changes in evaporation were not the principal causes of the strong dFe-salinity relationship. This suggests that precipitation is the primary cause of the high-Fe, low-salinity feature. Indeed, the volume-weighted mean $\mathrm{Fe}$ concentration for all rainwater samples near the equator was $310 \mathrm{n} M$ and therefore the flux due to the mixing of rain with surface water is sufficiently large to provide the required source of $\mathrm{dFe}$ to sustain the surface $\mathrm{dFe}$ maximum.

[19] Seawater dAl measurements provided useful supporting data to show the magnitude of previous dust deposition over the two transects due to its sufficiently long residence time in surface waters ( $\sim 5$ years) [Orians and Bruland, 1986]. The observed surface dAl features in Figures 2 and 3 were therefore indicative of integrated dust deposition flux over the past few years in the water masses sampled and showed a clear maximum at $0^{\circ}-10^{\circ} \mathrm{N}$. The fact that this is an accumulated pool is shown in the good consistency in surface dAl between the two cruises presented here and with data from other workers [Measures et al., 2008; Vink and Measures, 2001].

[20] On the other hand, seasonal changes are not well reflected by in situ surface dAl concentrations and horizontal advection may mask inputs predicted for local deposition fluxes by models and satellite data [Measures et al., 2008]. Similar to $\mathrm{dFe}, \mathrm{dAl}$ is efficiently removed by scavenging [Moran and Moore, 1988] but is not known to be utilized by microorganisms for biological processes. A lack of direct correlation between $\mathrm{dAl}$ and $\mathrm{dFe}$ is therefore not surprising.

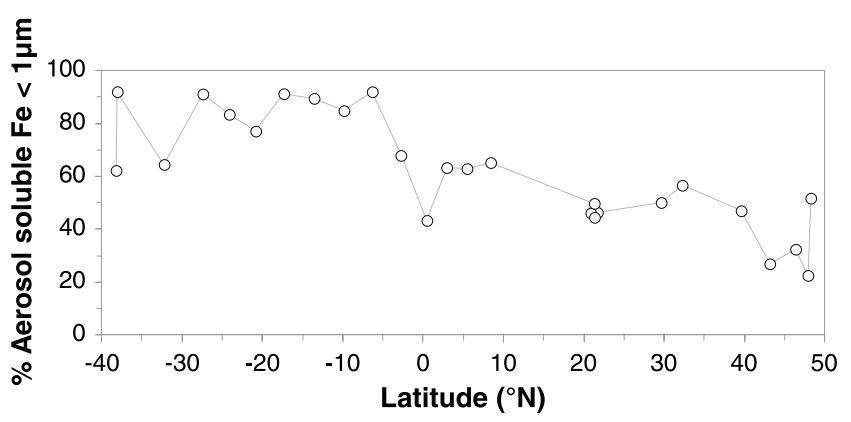

Figure 5. Aerosol size fractionation for AMT15. Shows the $\%$ fraction of soluble Fe in the "fine" $(<1 \mu \mathrm{m})$ aerosol fraction versus "total" aerosol soluble Fe (sum of Fe in both the "fine" and "coarse" (>1 $\mu \mathrm{m})$ aerosols). 


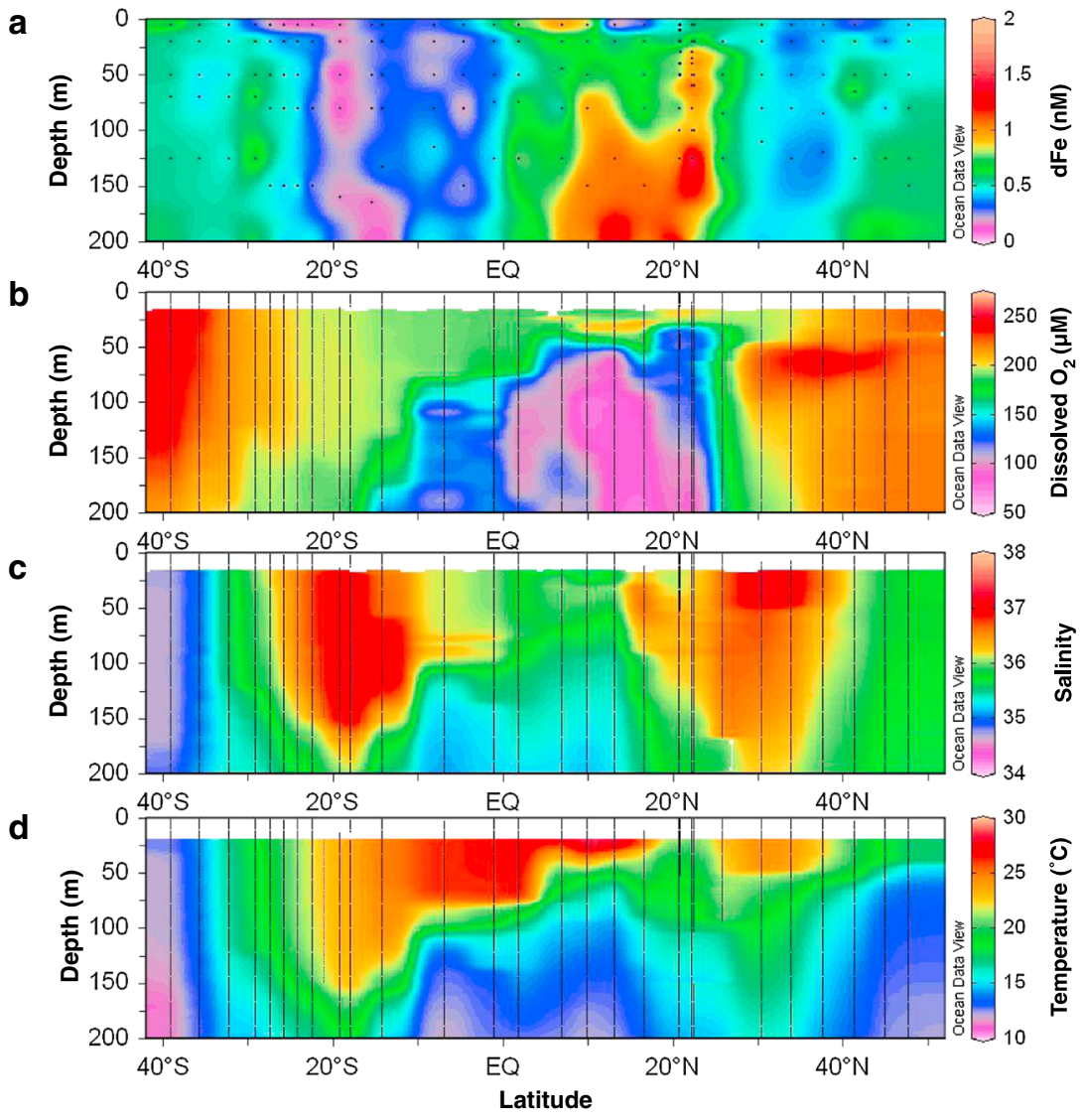

Figure 6. Upper water column section data $(0-200 \mathrm{~m})$ for AMT15. (a) Dissolved iron (dFe). (b) Dissolved oxygen $\left(\mathrm{O}_{2}\right)$. (c) Salinity. (d) Temperature.

The different active biogeochemical cycling of $\mathrm{dFe}$ and $\mathrm{dAl}$, which leads to different residence times, has been shown to have a profound influence on their distribution, such as opposing spatial trends in surface waters that receive high annual dust fluxes [Kramer et al., 2004].

\subsection{Size Fractionated Iron Distributions}

[21] Size fractionated Fe data (Figure 4) for surface seawater showed that the surface Fe maximum in the NATR $\left(12^{\circ} \mathrm{N}-30^{\circ} \mathrm{N}\right)$ was predominantly due to enhanced colloidal $(0.02-0.2 \mu \mathrm{m})$ and particulate $(>0.2 \mu \mathrm{m})$ Fe. The maximum in particulate $\mathrm{Fe}$ occurred in the region where the highest aerosol fluxes were observed. The residence time of this $\mathrm{Fe}$ fraction was sufficiently high to sustain these features, presumably due to sufficiently low sinking rates of colloids and fine particles, in addition to recycled $\mathrm{Fe}$ becoming associated with larger biogenic particles. In comparison, the size fractionation of the surface $\mathrm{Fe}$ maximum near the ITCZ showed a dominance of colloidal $\mathrm{Fe}$ and a lower contribution from particulate Fe. The inverse correlation of $\mathrm{dFe}$ with salinity mentioned above suggests that $\mathrm{Fe}$ in wet deposition results in accumulation of colloidal Fe that is sufficiently stable to be observed in these surface waters.

[22] Consistent with previous studies in the Atlantic [Sarthou et al., 2003; Buck et al., 2010b], aerosol size fractionation for AMT15 (Figure 5) showed a transition from coarse aerosol particles $(>1 \mu \mathrm{m})$, being the dominant source of soluble aerosol $\mathrm{Fe}(\sim 50-95 \%)$ in the North Atlantic, to fine particles $(<1 \mu \mathrm{m})$ in the South Atlantic. The lowest surface $\mathrm{dFe}, \mathrm{dAl}$, and atmospheric Fe concentrations were observed in the central South Atlantic Gyre for both cruises; this reflected the relatively low wet and dry deposition fluxes [Helmers and Schrems, 1995; Mahowald et al., 2009] to the SATL (Figures 2 and 3). Interestingly, the size fractionation analysis of $\mathrm{Fe}$ in seawater for AMT16 showed that $\mathrm{Fe}$ was predominantly $\mathrm{sFe}$ in this province. This different fractionation can be explained, for the most part, by the lower atmospheric fluxes and by different biogeochemical processing of $\mathrm{Fe}$ in these surface waters.

\subsection{Upper Water Column dFe Distributions}

[23] To comprehend the dFe distribution in the surface mixed layer, it was necessary to consider the Fe supply from below and indicators of remineralization. To do this, subsurface waters $(0-200$ and $0-300 \mathrm{~m})$ were sampled for both AMT15 and AMT16 cruises (Figures 6 and 7). For many of the provinces, the vertical dFe distribution was reasonably uniform, showing little variability across the upper thermocline, but strong latitudinal gradients between the geographical provinces were evident, with the lowest $\mathrm{dFe}$ concentrations $(<0.4 \mathrm{n} M)$ in the subtropical gyres. The most significant features of these sections were the high $\mathrm{dFe}(>0.8 \mathrm{n} M)$ waters observed in the upwelling water masses of the northern equatorial $\left(0^{\circ}-15^{\circ} \mathrm{N}\right)$ and Mauritanian shelf $\left(20^{\circ} \mathrm{N}-25^{\circ} \mathrm{N}\right.$, AMT15) regions (Figures 6a and 7a). In both cases, the maximum dFe 
USSHER ET AL.: SURFACE IRON IN THE ATLANTIC OCEAN

a

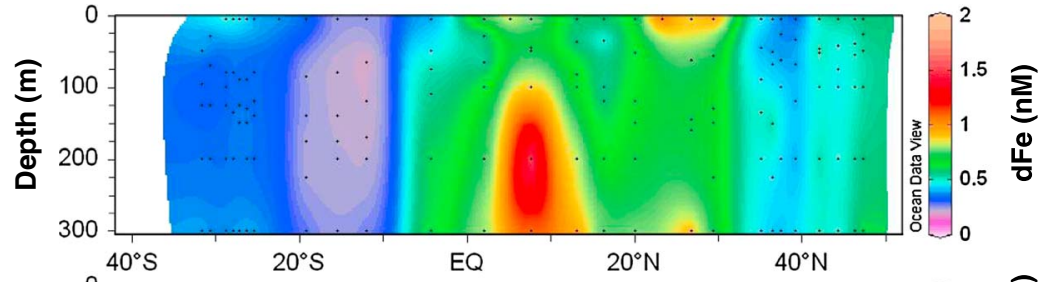

b
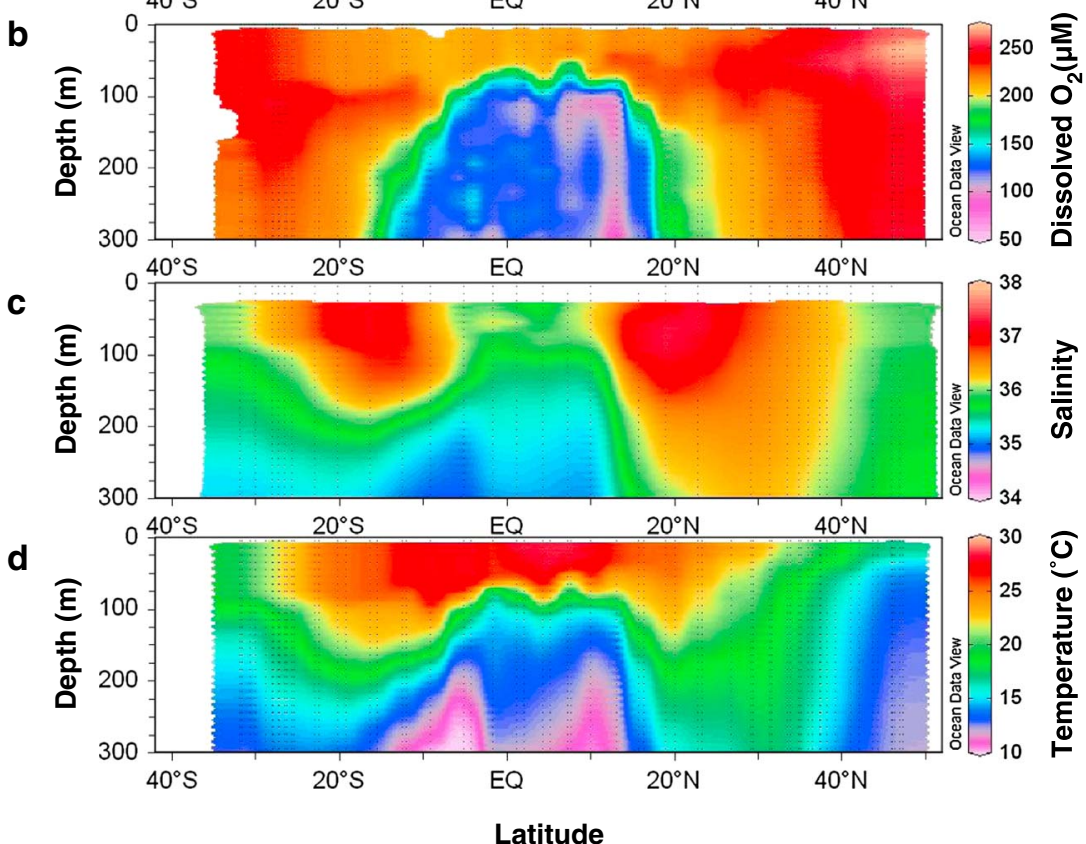

Figure 7. Upper water column section data (0-300 m) for AMT16. (a) Dissolved iron (dFe). (b) Dissolved oxygen $\left(\mathrm{O}_{2}\right)$. (c) Salinity. (d) Temperature.

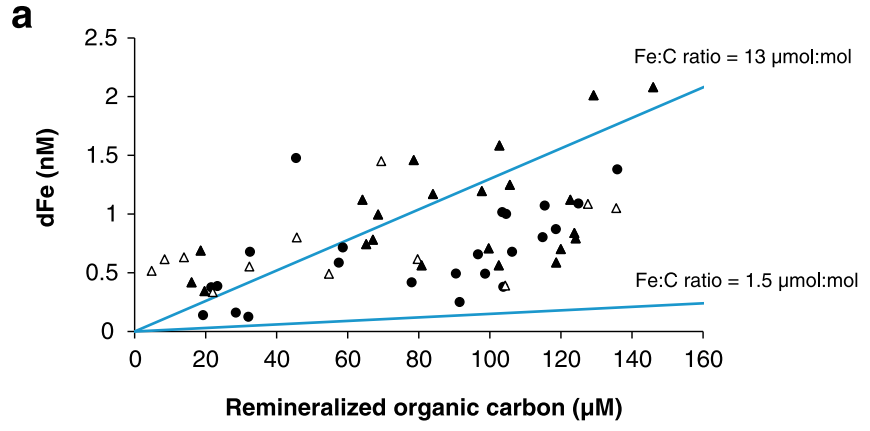

- Equatorial upwelling $\Delta$ Mauritanian Upwelling (off shelf) $\Delta$ Mauritanian upwelling (on shelf)

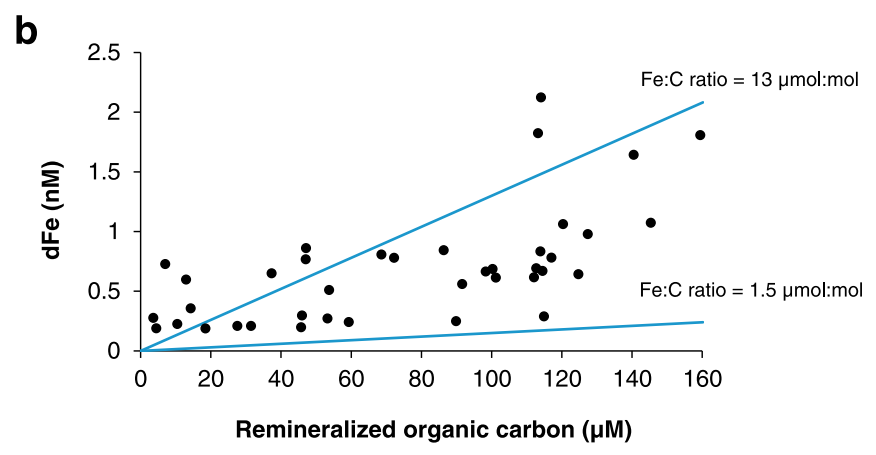

Figure 8. Relationship between remineralized organic carbon $\left(\mathrm{C}_{\text {org }}\right)$ and $\mathrm{dFe}$ for samples beneath the mixed layer in the tropical Atlantic Ocean, for (a) AMT15 and (b) AMT16 cruises. 

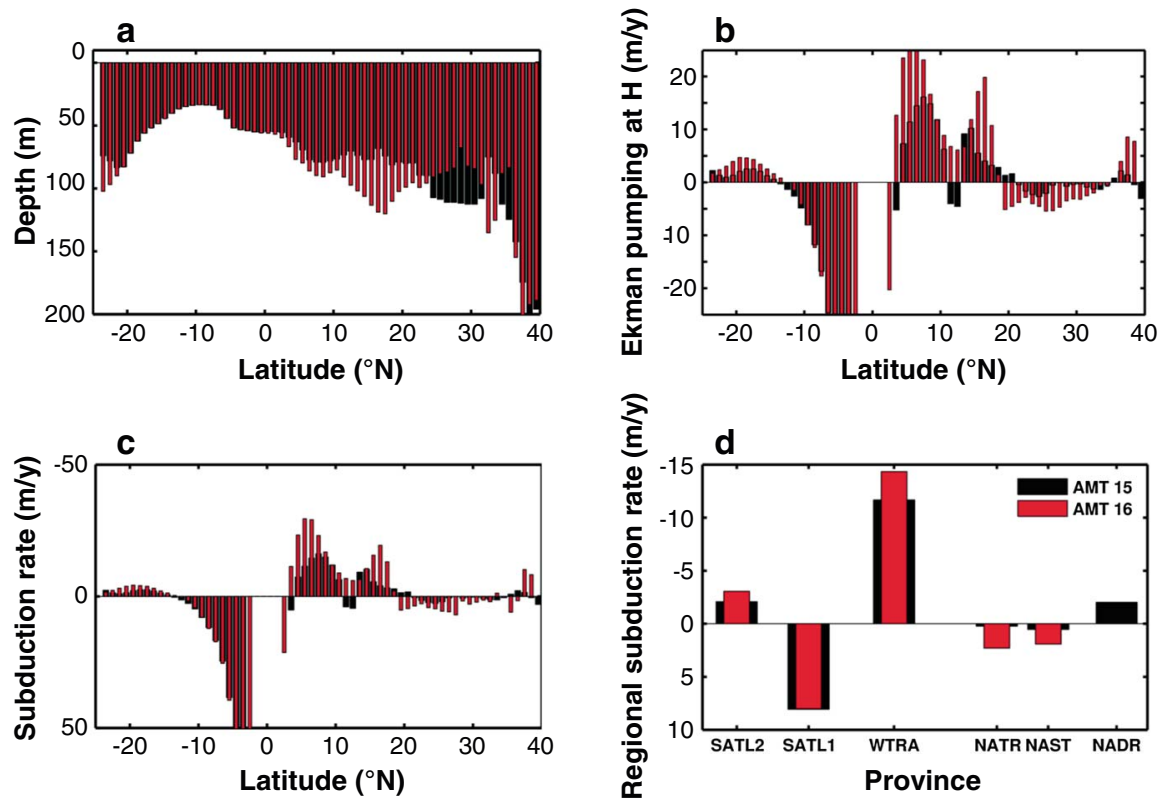

Figure 9. Latitudinal variation of (a) winter mixed layer depth, (b) annual estimates of Ekman pumping vertical velocity at the bottom of the mixed layer, (c) annual subduction rates resulting from equation (1), and (d) annual subduction rates averaged for each of the Longhurst regions (where negative subduction shows upward transport). Black bars indicate AMT15 data, and red bars are AMT16 data.

concentrations occurred within upwelled water containing low dissolved oxygen $(<150 \mu M$; Figures $6 \mathrm{~b}$ and $7 \mathrm{~b})$.

[24] The consistency between cruises and with similar studies [Bergquist and Boyle, 2006; Measures et al., 2008] confirms this "fountain" of $\mathrm{dFe}$ to be a permanent feature in the WTRA. This is likely to be maintained by production of Fe (II) under low-oxygen conditions (S. J. Ussher et al., manuscript in preparation, 2013) and bacterial remineralization of biogenic particulate iron with consequential production of $\mathrm{Fe}$ binding ligands [Boyd et al., 2010; Schlosser and Croot, 2009].

[25] The $\mathrm{dFe}$ concentrations in these subsurface water masses could result from a combination of inputs via (i) organic carbon $\left(\mathrm{C}_{\mathrm{org}}\right)$ remineralization, (ii) dissolution of lithogenic colloids derived from the northwest African shelf, and (iii) dissolution of $\mathrm{Fe}$ from atmospheric particles. To assess which processes were dominant, $\mathrm{Fe}: \mathrm{C}_{\text {org }}$ ratios below the mixed layer of the WTRA were calculated by converting apparent oxygen utilization into remineralized $\mathrm{C}_{\text {org }}$ (using an $-\mathrm{O}_{2}: \mathrm{C}_{\text {org }}$ ratio of 1.39 [Anderson, 1995]). A direct comparison of $\mathrm{dFe}$ below the surface mixed layer and estimated organic carbon prior to remineralization (Figure 8) showed that $\mathrm{Fe}: \mathrm{C}_{\text {org }}$ ratios were, for the most part, within the range reported for phytoplankton in open-ocean waters (1.5-13 $\mu \mathrm{mol} \mathrm{mol}^{-1}$ ) [Sunda, 1997], with $\sim 30-40 \%$ of the data higher than this range.

[26] The distributions show agreement with $\mathrm{Fe}: \mathrm{C}$ ratios reported for this region by other workers [Bergquist and Boyle, 2006; Rijkenberg et al., 2012] and suggest that a significant fraction of $\mathrm{Fe}$ in the low-oxygen subsurface and intermediate waters of this region would have been derived from biogenic material. However, the origin of enhanced $\mathrm{dFe}$ in upwelled water, far away from the shelf, is likely to be atmospheric $\mathrm{Fe}$ that has been incorporated in biota, exported and remineralized. Similar to Measures et al.
[2008], low-temperature, low- $\mathrm{O}_{2}$ upwelled water was observed south of the dFe plume that was not associated with elevated $\mathrm{dFe}$. On the other hand, separation of the data into regions showed consistently elevated $\mathrm{Fe}: \mathrm{C}_{\text {org }}$ ratios $(>13$ $\left.\mu \mathrm{mol} \mathrm{mol}{ }^{-1}\right)$ in the Mauritanian oxygen minimum zone (OMZ) (Figure 8a), which indicate a lithogenic source near the shelf or higher uptake ratios of $\mathrm{Fe}: \mathrm{C}_{\text {org }}$ by primary producers in this region.

\subsection{Vertical Subduction Fluxes Across the Thermocline}

[27] To estimate the downwelling/upwelling flux of $\mathrm{dFe}$ in the different provinces along the two AMT transects, the annual flux of water volume between the mixed layer and the permanent thermocline was calculated. This allowed vertical water column fluxes to be compared with atmospheric deposition fluxes and to estimate $\mathrm{dFe}$ residence times in the mixed layer. The methodology for calculating subduction fluxes follows Marshall et al. [1993] and requires solving equation (1):

$$
S_{a n n}=\overline{-W_{E k}}+\frac{\beta}{f} \int_{-H}^{0} \bar{v} \mathrm{~d} z-\overline{\boldsymbol{u}_{H}} \cdot \Delta H
$$

where the vertical velocity at the base of the mixed layer has been related to the Ekman pumping using the linear vorticity balance. In equation (1), the overbar denotes an annual average, $S_{a n n}$ is then the annual subduction of water into the permanent thermocline, $W_{E k}$ is the Ekman pumping vertical velocity induced by surface winds, $f$ is the planetary vorticity, and $\beta$ is its gradient; $v$ is the meridional velocity integrated between the surface and the depth of the winter mixed layer $H$ and $\boldsymbol{u}$ is the velocity at the base of the winter mixed layer.

[28] To evaluate equation (1) along the AMT transects, the winter mixed layer depth was collated from a global 


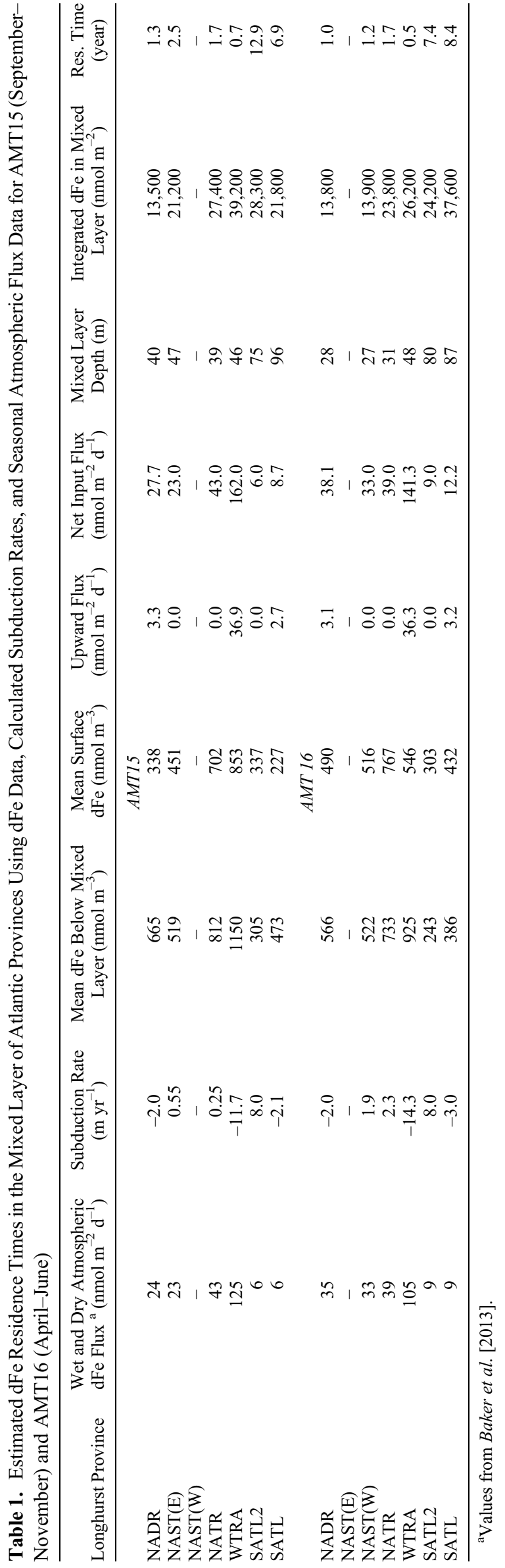

climatology of $0.25^{\circ}$ resolution generated from the National Centers for Environmental Prediction (NCEP)/National Center for Atmospheric Research (NCAR) 50 year reanalysis data set [Kistler et al., 2001]. The maximum winter values for each of the data points closest to the AMT tracks were selected. Surface winds used in the calculation of the Ekman pumping velocity were obtained from 10 years (2000-2010) of ECMWF ERA-Interim reanalysis data. Ocean currents were obtained in each of the AMTs by the onboard $75 \mathrm{kHz}$ RDI VMADCP (Teledyne RD Instruments Vessel Mounted Acoustic Doppler Current Profiler). The data have been processed using the CODAS software and processing steps (see http://currents.soest.hawaii.edu/docs/doc/codas_doc/index.html for a detailed description of the methodology). The closest available data to the AMT hourly averaged tracks were selected and further averaged to $1^{\circ}$ resolution.

[29] The largest differences between the two AMT cruises reflect the different tracks followed by each cruise. This is especially true in Figure 9a, as location is the only determinand used in the selection of the winter mixed layer depth. As previously mentioned, the AMT15 track went closer to the African coast (hence the shallower mixed layer depths in the north equatorial region).

[30] The general trend is one of decreasing depths toward the equator. The Ekman pumping (positive reflects upwelling; Figure 9b) climatology along both tracks reflects the mean wind circulation in the northern and southern gyres as well as the strong divergence along the north equatorial region. No values are shown for the equatorial region as the coriolis parameter tends to zero there. The largest variability in Ekman pumping was associated with the equatorial and tropical region $\left(10^{\circ} \mathrm{S}\right.$ to $\left.10^{\circ} \mathrm{N}\right)$. The north gyre subduction region is clearly defined but is not present in the South Atlantic in which the AMT tracks cover a region of weak upwelling. Climatological Ekman pumping downwelling in the South Atlantic starts from $40^{\circ} \mathrm{S}$. Figure $9 \mathrm{c}$ shows the annual subduction volume fluxes at $1^{\circ}$ resolution while Figure $9 \mathrm{~d}$ represents volume fluxes averaged over the area of the provinces. Small differences can be noted between the AMT cruises although the sign of the flux is consistent in both.

[31] Apparent in Figure 9 is a marked asymmetry in the latitudinal averaged annual subduction rates around the equator, with larger values north of the equator. During both AMT cruises, the ITCZ was north of its early boreal spring location and consequently, the associated peak in Ekman pumping was also shifted northward [Doi et al., 2010]. The sharp decrease in subduction rates south of the equator (Figure 9c) is also linked to the Atlantic Meridional Mode (AMM), a climate mode associated with the cross-equatorial meridional gradient of the sea surface temperature anomaly in the tropical Atlantic [Xie and Carton, 2004). AMT16 took place during a positive AMM phase, which would drive a stronger Ekman upwelling north of the equator and a sharp decrease south of it, as reflected in our calculations shown in Figures 9b-9d.

\subsection{Regional dFe Mixed Layer Residence Times}

[32] The dFe distributions from the two Atlantic transects (Figures 6 and 7) indicated marked differences between atmospheric and upwelling fluxes in the North and South Atlantic. To interpret this further, surface mixed layer residence times were estimated for different Atlantic regions. 
a

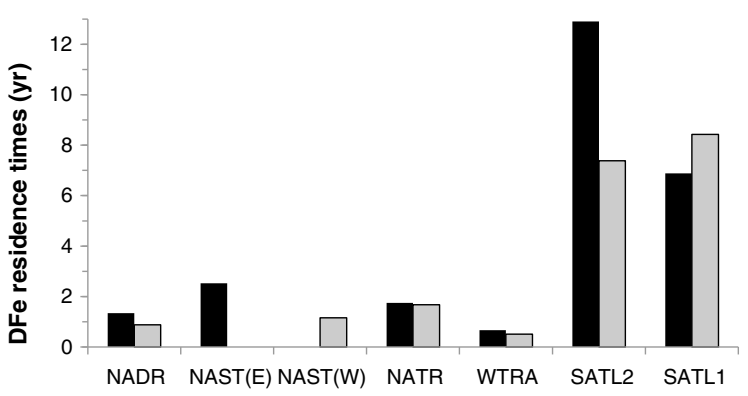

b

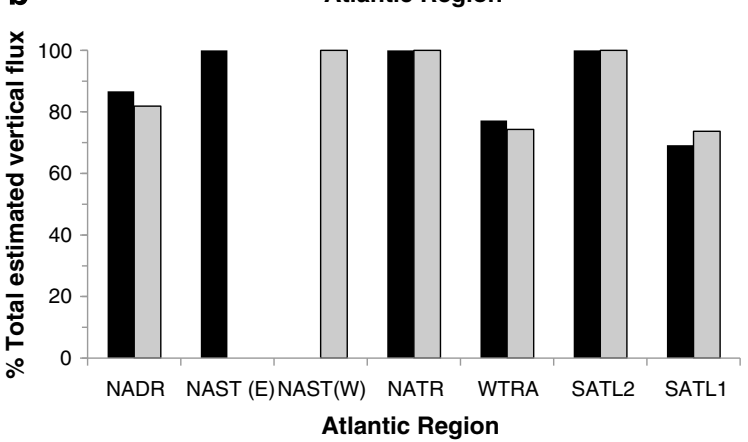

Figure 10. (a) Seasonal $\mathrm{dFe}$ residence time estimates for Atlantic provinces using AMT15 (black bars) and AMT16 (grey bars) data. (b) Atmospheric fluxes as a percentage of total estimated dFe vertical flux for the same provinces are shown using seasonal flux data for AMT15 (black bars) and AMT16 (grey bars).

The residence time calculations included seasonal atmospheric fluxes (see below) and the Fe fluxes to the surface mixed layer due to vertical mixing calculated from vertical and horizontal velocities [Marshall et al., 1993] (Figure 9). To calculate mixed layer residence times (Table 1), mean $\mathrm{dFe}$ data were calculated for each Atlantic province for each cruise. Due to the contrasting vertical mixing in the north and south South Atlantic Gyral Province (SATL) mentioned above, this region was split into two provinces: SATL1 $\left(15^{\circ} \mathrm{S}-40^{\circ} \mathrm{S}\right)$ and SATL2 $\left(5^{\circ} \mathrm{S}-15^{\circ} \mathrm{S}\right)$.

[33] For all regions, average seasonal wet and dry atmospheric deposition fluxes were calculated (Figures $2 \mathrm{f}$ and $3 \mathrm{f}$ and Table 1), in order to allow for the short-term (daily) spatial and temporal variability of atmospheric dust deposition. These were climatological mean fluxes for 3 month periods, estimated using results from rain and aerosol collections during several basin-scale cruises through the Atlantic (three cruises, including AMT16, during April-June and nine cruises, including AMT15, during September-November). The methods used were similar to those used to estimate atmospheric nitrogen inputs to the Atlantic [Baker et al., 2010] and are described in detail elsewhere [Baker et al., 2013].

[34] To convert the regional subduction rates $\left(S_{\text {ann }}\right)$ between the mixed layer and the permanent thermocline to regional $\mathrm{dFe}$ fluxes, mean regional mixed layer depths were used from in situ CTD data. The calculated mean of dFe data below the mean winter mixed layer depth (Figure 9a) for each individual province was used to estimate the upward flux of $\mathrm{dFe}$ when subduction was predominantly in an upward direction (negative number).
[35] The sum of both seasonal atmospheric flux and any upward Fe flux to the surface mixed layer due to vertical mixing gives an estimate of the vertical input flux of both atmospheric input and vertical water movement (defined as net input flux in Table 1). Vertical $\mathrm{dFe}$ input fluxes ranged within $20-170 \mathrm{nmol} \mathrm{m}^{-2} \mathrm{~d}^{-1}$ in the North Atlantic and 6-13 nmol m${ }^{-2} \mathrm{~d}^{-1}$ in the South Atlantic. The highest $\mathrm{dFe}$ flux from vertical mixing alone was found in the western tropics $\left(35-40 \mathrm{nmol} \mathrm{m}^{-2} \mathrm{~d}^{-1}\right)$.

[36] The resulting mixed layer residence times (Figure 10a) showed a consistent difference between the North and South Atlantic Gyres for both cruises, from 1-3 years in the NAST to 6-13 years in the southern gyre. Furthermore, atmospheric flux was found to be $>50 \%$ of the total $\mathrm{dFe}$ vertical input flux into the mixed layer in all the regions studied (Figure 10b), even where significant upwelling occurred. The size speciation of $\mathrm{Fe}$ in the water column appears to be connected to residence time with a low proportion of $\mathrm{Fe}$ in the SATL associated with particles and colloids (Figures 2-4). We hypothesize that the difference in residence times between the northern and southern gyres is caused by lower atmospheric Fe inputs and more efficient biological uptake and recycling of $\mathrm{sFe}$ in the South Atlantic gyre. This is further supported by observations of lower particle export in the South Atlantic [Charette and Moran, 1999].

[37] In contrast, the WTRA had low dFe residence times (6-8 months) due to high inputs of Fe (associated with particles and colloids), high annual productivity, and high particulate organic carbon flux [Charette and Moran, 1999]. The overall trend in upper water column residence times for all provinces is similar to that observed for ${ }^{230} \mathrm{Th}$ and ${ }^{234} \mathrm{Th}$ residence times in surface Atlantic seawater which ranged from 0.2 to 4 years in the subtropical gyres but decreased notably in the WTRA [Hsieh et al., 2011].

[38] The residence times presented here provide an estimate of the characteristic response time of the reservoir to imbalances in the input and removal fluxes in the case of a net input flux or a net removal flux. However, they should be considered approximations as a steady state is assumed in a highly dynamic environment of variable inputs and rapid biogeochemical cycling. The uncertainties in the residence time calculations reflect the inherent variability in atmospheric inputs, surface water concentrations and loss from the mixed layer for a biogeochemically active component such as dFe. To reduce the uncertainty, $\mathrm{dFe}$ concentrations have been averaged across the province and seasonal (3 month average) atmospheric fluxes were used. Similarly, to reduce uncertainty from local variability in upwelling and downwelling due to Ekman pumping, the subduction fluxes from the in situ physical data were averaged across provinces.

[39] The paucity of atmospheric deposition data remains a major uncertainty in these calculations. Atmospheric fluxes have a strong seasonality, particularly in the NATR region [Powell, 2010; Baker et al., 2013]. The annual average soluble Fe deposition flux estimated for this region is approximately double the seasonal flux used here. This suggests that the residence time estimates for this region reported here ( $\sim 1.5$ years) are likely to be overestimates. For the western NAST, an average Fe deposition flux at Bermuda can be estimated from a 2 year sampling period $\left(172 \mu \mathrm{g} \mathrm{m}^{-2} \mathrm{~d}^{-1}[\right.$ Tian et al., 2008]). If a fractional solubility range of $6 \pm 5 \%$ 
$(\mathrm{n}=18)$ [Sedwick et al., 2007] is assumed and the same subduction flux is used from Table 1 , the estimated $\mathrm{dFe}$ residence time for the western NAST is 40-450 days, compared with the 420 days calculated using the shipboard AMT aerosol fluxes. Hence, the latter residence time is also likely to be an overestimate and suggests annual replenishment of the dFe pool in surface waters. Seasonality is less pronounced elsewhere along the transect, although even the South Atlantic demonstrates seasonality of dust supply, based on model estimates [Johnson et al., 2010].

[40] This analysis emphasizes that residence time estimates of surface water $\mathrm{dFe}$ based on steady state assumptions are simplifications but, when combined with vertical subduction fluxes, can at least provide an indication of the likely characteristic response times of surface water $\mathrm{dFe}$ to the temporally and spatially variable input and removal processes. It is clear that North Atlantic regions have dFe pools in the surface mixed layer that are completely replenished within a time scale of several months to 2-3 years. The analysis also suggests that regardless of uncertainties and variability in atmospheric deposition fluxes, there is a systematic difference in residence times of $\mathrm{dFe}$ between the North and South Atlantic gyre regions, reflecting differences in water column biogeochemical processes.

\section{Conclusion}

[41] Overall, the AMT data showed basin-scale differences in the Atlantic surface Fe inventory that are consistent with modeled $\sim 10$-fold difference in dust fluxes between the North (6.38 $\mathrm{Tg}^{-1}$ ) and South Atlantic (0.68 $\left.\mathrm{Tg} \mathrm{yr}^{-1}\right)$ [Mahowald et al., 2009]. Upwelling and vertical mixing of $\mathrm{dFe}$ into the mixed layer were more important in the tropics and eastern boundaries but over the entire basin they were not as dominant as atmospheric fluxes, which were $>50 \%$ of the total vertical dFe flux. The study revealed very different biogeochemical cycling and fluxes of $\mathrm{dFe}$ in the North and South Atlantic Gyres, with higher residence times ( $>5$ years) in the South Atlantic Gyre, where sFe was the dominant size fraction. The large variability in Fe concentrations in the upper water column is clearly sufficient to influence primary production and nitrogen fixation in the different Atlantic regions. We suggest this effect will be evident in other regions, including the Pacific and Indian Oceans, where there are also large-scale regional differences in atmospheric Fe fluxes.

[42] The most significant Fe flux from vertical mixing was found in the tropics $\left(\sim 40 \mathrm{nmol} \mathrm{m}^{-2} \mathrm{~d}^{-1}\right)$, where a plume of high $\mathrm{dFe}$ in the low-oxygen/suboxic subsurface waters extended from Mauritania into the center of the tropical upwelling region, fueled by high atmospheric deposition fluxes. If enhanced concentrations of $\mathrm{dFe}$ are stabilized in these lowoxygen water masses, as suggested here, then future expansion of OMZs [Stramma et al., 2008] may significantly increase the $\mathrm{dFe}$ inventory in the tropical and subtropical Atlantic.

[43] Acknowledgments. We thank the officers and crew of the RRS Discovery during AMT15 and AMT16 and E. Mawji and M. Waeles for their assistance with the trace metal casts and aerosol collection. The work was supported by a Marie Curie IOF within the 7th European Community Framework Programme (SOLAIROS project, PIOF-GA-2009-235418) awarded to S.J.U. and the following UK grants: (i) NERC grant NER/A/S/ 2003/00489 to S.J.U., P.J.W., and E.P.A.; (ii) AMT Consortium (NERC grant NER/O/S2001/00680); and (iii) grant NE/c001737/1 to T.D.J. and A. R.B. All supporting oceanographic data were supplied by the British
Oceanographic Data Centre (BODC), and data from this article remain available from this source (http://www.bodc.ac.uk/projects/uk/amt) and can be accessed on request. This is contribution 221 of the AMT programme.

\section{References}

Anderson, L. A. (1995), On the hydrogen and oxygen content of marine phytoplankton, Deep Sea Res., Part I, 42(9), 1675-1680.

Baker, A. R., T. D. Jickells, M. Witt, and K. L. Linge (2006a), Trends in the solubility of iron, aluminium, manganese and phosphorus in aerosol collected over the Atlantic Ocean, Mar. Chem., 98(1), 43-58.

Baker, A. R., T. D. Jickells, K. F. Biswas, K. Weston, and M. French (2006b), Nutrients in atmospheric aerosol particles along the Atlantic Meridional Transect, Deep Sea Res., Part II, 53(14-16), 1706-1719, doi:10.1016/j.dsr2.2006.05.012.

Baker, A. R., K. Weston, S. D. Kelly, M. Voss, P. Streu, and J. N. Cape (2007), Dry and wet deposition of nutrients from the tropical Atlantic atmosphere: Links to primary productivity and nitrogen fixation, Deep Sea Res. Oceanogr. Res., Part I, 54(10), 1704-1720.

Baker, A. R., T. Lesworth, C. Adams, T. D. Jickells, and L. Ganzeveld (2010), Estimation of atmospheric nutrient inputs to the Atlantic Ocean from $50^{\circ} \mathrm{N}$ to $50^{\circ} \mathrm{S}$ based on large-scale field sampling: Fixed nitrogen and dry deposition of phosphorus, Global Biogeochem. Cycles, 24, GB3006, doi:10.1029/2009GB003634.

Baker, A. R., C. Adams, T. G. Bell, T. D. Jickells, and L. Ganzeveld (2013), Estimation of atmospheric nutrient inputs to the Atlantic Ocean from $50^{\circ} \mathrm{N}$ to $50^{\circ} \mathrm{S}$ based on large-scale field sampling: Iron and other dust-associated elements, Global Biogeochem. Cycles, 27, 755-767, doi:10.1002/ gbc. 20062.

Bergquist, B. A., and E. A. Boyle (2006), Dissolved iron in the tropical and subtropical Atlantic Ocean, Global Biogeochem. Cycles, 20, GB1015, doi:10.1029/2005GB002505.

Bergquist, B. A., J. Wu, and E. A. Boyle (2007), Variability in oceanic dissolved iron is dominated by the colloidal fraction, Geochim. Cosmochim. Acta, 71(12), 2960-2974.

Blain, S., U. Guieu, H. Claustre, K. Leblanc, T. Moutin, B. Queguiner, J. Ras, and G. Sarthou (2004), Availability of iron and major nutrients for phytoplankton in the northeast Atlantic Ocean, Limnol. Oceanogr., 49(6), 2095-2104.

Bowie, A. R., E. P. Achterberg, R. F. C. Mantoura, and P. J. Worsfold (1998), Determination of sub-nanomolar levels of iron in seawater using flow injection with chemiluminescence detection, Anal. Chim. Acta, 361(3), 189-200.

Bowie, A. R., D. J. Whitworth, E. P. Achterberg, R. F. C. Mantoura, and P. J. Worsfold (2002), Biogeochemistry of Fe and other trace elements (Al, Co, Ni) in the upper Atlantic Ocean, Deep Sea Res., Part I, 49(4), 605-636.

Bowie, A. R., E. P. Achterberg, P. L. Croot, H. J. W. de Baar, P. Laan, J. W. Moffett, S. Ussher, and P. J. Worsfold (2006), A community-wide intercomparison exercise for the determination of dissolved iron in seawater, Mar. Chem., 98(1), 81-99.

Bowie, A. R., S. J. Ussher, W. M. Landing, and P. J. Worsfold (2007), Intercomparison between FI-CL and ICP-MS for the determination of dissolved iron in Atlantic seawater, Environ. Chem., 4(1), 1-4.

Boyd, P. W., E. Ibisanmi, S. G. Sander, K. A. Hunter, and G. A. Jackson (2010), Remineralization of upper ocean particles: Implications for iron biogeochemistry, Limnol. Oceanogr., 55(3), 1271-1288.

Buck, C. S., W. M. Landing, J. A. Resing, and C. I. Measures (2010a), The solubility and deposition of aerosol Fe and other trace elements in the North Atlantic Ocean: Observations from the A16N CLIVAR/CO2 repeat hydrography section, Mar. Chem., 120(1-4), 57-70.

Buck, C. S., W. M. Landing, and J. A. Resing (2010b), Particle size and aerosol iron solubility: A high-resolution analysis of Atlantic aerosols, Mar. Chem., 120(1-4), 14-24.

Charette, M. A., and S. B. Moran (1999), Rates of particle scavenging and particulate organic carbon export estimated using 234Th as a tracer in the subtropical and equatorial Atlantic Ocean, Deep Sea Res., Part II, 46(5), 885-906.

Doi, T., T. Tozuka, and T. Yamagata (2010), The Atlantic Meridional Mode and its coupled variability with the Guinea Dome, J. Clim., 23(2), $455-475$.

Duce, R. A., and N. W. Tindale (1991), Atmospheric transport of iron and its deposition in the ocean, Limnol. Oceanogr., 36(8), 1715-1726.

Elrod, V. A., W. M. Berelson, K. H. Coale, and K. S. Johnson (2004), The flux of iron from continental shelf sediments: A missing source for global budgets, Geophys. Res. Lett., 31, L12307, doi:10.1029/ 2004 GL020216.

Fratantoni, D. M. (2001), North Atlantic surface circulation during the 1990s observed with satellite-tracked drifters, J. Geophys. Res., 106, 22,067-22,093. 
Helmers, E., and O. Schrems (1995), Wet deposition of metals to the tropical North and the South Atlantic Ocean, Atmos. Environ., 29(18), 2475-2484.

Hsieh, Y.-T., G. M. Henderson, and A. L. Thomas (2011), Combining seawater $232 \mathrm{Th}$ and $230 \mathrm{Th}$ concentrations to determine dust fluxes to the surface ocean, Earth Planet. Sci. Lett., 312(3-4), 280-290.

Hydes, D. J., and P. S. Liss (1976), Fluorimetric method for determination of low concentrations of dissolved aluminum in natural-waters, Analyst, 101(1209), 922-931

Jickells, T. D. (1999), The inputs of dust derived elements to the Sargasso Sea; a synthesis, Mar. Chem., 68(1-2), 5-14.

Johnson, K. S., et al. (2007), Developing standards for dissolved iron in seawater, Eos. Trans. $A G U, 88(11), 131$.

Johnson, M. S., N. Meskhidze, F. Solmon, S. Gassó, P. Y. Chuang, D. M. Gaiero, R. M. Yantosca, S. Wu, Y. Wang, and C. Carouge (2010), Modeling dust and soluble iron deposition to the South Atlantic Ocean, J. Geophys. Res., 115, D15202, doi:10.1029/2009JD013311.

Kaufman, Y. J., I. Koren, L. A. Remer, D. Tanre, P. Ginoux, and S. Fan (2005), Dust transport and deposition observed from the Terra-Moderate Resolution Imaging Spectroradiometer (MODIS) spacecraft over the Atlantic Ocean, J. Geophys. Res., 110, D10S12, doi:10.1029/ 2003JD004436.

Kistler, R., et al. (2001), The NCEP-NCAR 50 year reanalysis: Monthly means CD-ROM and documentation, Bull. Am. Meteorol. Soc., 82(2), 247-267.

Kramer, J., P. Laan, G. Sarthou, K. R. Timmermans, and H. J. W. de Baar (2004), Distribution of dissolved aluminium in the high atmospheric input region of the subtropical waters of the North Atlantic Ocean, Mar. Chem. $88(3-4), 85-101$.

Lentz, S. J. (1995), Seasonal-variations in the horizontal structure of the Amazon plume inferred from historical hydrographic data, J. Geophys. Res., 100, 2391-2400.

Longhurst, A. (1998), Ecological Geography of the Sea, Academic, London

Mahaffey, C., R. G. Williams, G. A. Wolff, and W. T. Anderson (2004), Physical supply of nitrogen to phytoplankton in the Atlantic Ocean, Global Biogeochem. Cycles, 18, GB1034, doi:10.1029/ 2003GB002129.

Mahowald, N. M., et al. (2009), Atmospheric iron deposition: Global distribution, variability, and human perturbations, Annu. Rev. Mar. Sci., 1, $245-278$.

Marshall, J. C., A. J. G. Nurser, and R. G. Williams (1993), Inferring the subduction rate and period over the North Atlantic, J. Phys. Oceanogr., 23(7), 1315-1329.

Martin, J. H., S. E. Fitzwater, R. M. Gordon, C. N. Hunter, and S. J. Tanner (1993), Iron, primary production and carbon-nitrogen flux studies during the JGOFS North Atlantic Bloom Experiment, Deep Sea Res., Part II, 40(1-2), 115-134.

Measures, C. I., W. M. Landing, M. T. Brown, and C. S. Buck (2008), Highresolution $\mathrm{Al}$ and $\mathrm{Fe}$ data from the Atlantic Ocean CLIVAR-CO(2) repea hydrography A16N transect: Extensive linkages between atmospheric dus and upper ocean geochemistry, Global Biogeochem. Cycles, 22, GB1005, doi:10.1029/2007GB003042.

Mills, M. M., C. Ridame, M. Davey, J. La Roche, and R. J. Geider (2004), Iron and phosphorus co-limit nitrogen fixation in the eastern tropical North Atlantic, Nature, 429(6989), 292-294.

Moore, J. K., S. C. Doney, D. M. Glover, and I. Y. Fung (2002), Iron cycling and nutrient-limitation patterns in surface waters of the World Ocean, Deep Sea Res., Part II, 49(1-3), 463-507.

Moore, C. M., M. M. Mills, A. Milne, R. Langlois, E. P. Achterberg, K. Lochte, R. J. Geider, and J. La Roche (2006), Iron limits primary productivity during spring bloom development in the central North Atlantic, Global Change Biol., 12(4), 626-634.

Moore, C. M., et al. (2009), Large-scale distribution of Atlantic nitrogen fixation controlled by iron availability, Nat. Geosci., 2(12), 867-871.

Moran, S. B., and R. M. Moore (1988), Evidence from mesocosm studies for biological removal of dissolved aluminium from sea water, Nature, 335(6192), 706-708.

Orians, K. J., and K. W. Bruland (1986), The biogeochemistry of aluminum in the Pacific Ocean, Earth Planet. Sci. Lett., 78(4), 397-410.

Parekh, P., M. J. Follows, and E. Boyle (2004), Modeling the global ocean iron cycle, Global Biogeochem. Cycles, 18, GB1002, doi:10.1029/ 2003GB002061

Powell, C. (2010), Atmospheric inputs of iron and other key nutrients to the Tropical North Atlantic, PhD Thesis, Univ. of East Anglia, Norwich, Norfolk, U. K.

Rijkenberg, M., S. Steigenberger, C. Powell, H. van Haren, M. D. Patey, A. R. Baker, and E. P. Achterberg (2012), Fluxes and distribution of dissolved iron in the eastern (sub-) tropical North Atlantic Ocean, Global Biogeochem. Cycles, 26, GB3004, doi:10.1029/2011GB004264.

Sarthou, G., et al. (2003), Atmospheric iron deposition and sea-surface dissolved iron concentrations in the eastern Atlantic Ocean, Deep Sea Res., Part I, 50(10-11), 1339-1352.

Schlosser, C., and P. L. Croot (2009), Controls on seawater Fe(III) solubility in the Mauritanian upwelling zone, Geophys. Res. Lett., 36, L18606, doi:10.1029/2009GL038963.

Sedwick, P. N., E. R. Sholkovitz, and T. M. Church (2007), Impact of anthropogenic combustion emissions on the fractional solubility of aerosol iron: Evidence from the Sargasso Sea, Geochem. Geophys. Geosyst., 8, Q10Q06, doi:10.1029/2007GC001586.

Shelley, R. U., et al. (2012), Controls on dissolved cobalt in surface waters of the Sargasso Sea: Comparisons with iron and aluminum, Global Biogeochem. Cycles, 26, GB2020, doi:10.1029/2011GB004155.

Stramma, L., G. C. Johnson, J. Sprintall, and V. Mohrholz (2008), Expanding oxygen-minimum zones in the tropical oceans, Science, 320(5876), 655-658 Sunda, W. G. (1997), Control of dissolved iron concentrations in the world ocean, a comment, Mar. Chem., 57(3-4), 169-172.

Tagliabue, A., et al. (2010), Hydrothermal contribution to the oceanic dissolved iron inventory, Nat. Geosci., 3(4), 252-256.

Tian, Z., P. Olliver, A. Véron, and T. M. Church (2008), Atmospheric Fe deposition modes at Bermuda and the adjacent Sargasso Sea, Geochem Geophys. Geosyst., 9, Q08007, doi:10.1029/2007GC001868.

Ussher, S. J., P. J. Worsfold, E. P. Achterberg, A. Laës, S. Blain, P. Laan, and H. J. W. de Baar (2007), Distribution and redox speciation of dissolved iron on the European continental margin, Limnol. Oceanogr., 52(6), 2530-2539.

Ussher, S. J., I. Petrov, C. R. Quétel, and P. J. Worsfold (2010), Validation of a portable flow injection-chemiluminescence (FI-CL) method for the determination of dissolved iron in Atlantic open ocean and shelf waters by comparison with isotope dilution-inductively coupled plasma mass spectrometry (ID-ICPMS), Environ. Chem., 7(2), 139-145.

Vink, S., and C. I. Measures (2001), The role of dust deposition in determining surface water distributions of $\mathrm{Al}$ and $\mathrm{Fe}$ in the South West Atlantic, Deep Sea Res., Part II, 48(13), 2787-2809.

Wilcox, E. M., K. M. Lau, and K. M. Kim (2010), A northward shift of the North Atlantic Ocean Intertropical Convergence Zone in response to summertime Saharan dust outbreaks, Geophys. Res. Lett., 37, L04804, doi:10.1029/2009GL041774.

Xie, S.-P., and J. A. Carton (2004), Tropical Atlantic variability: Patterns, mechanisms, and impacts, in Earth's Climate: The Ocean-Atmosphere Interaction Geophys. Monogr. Ser., vol. 147, pp. 121-142, AGU, Washington, D. C. 